\title{
Economic changes and investment in higher education in Brazil 2000-2015
}

DOI: $10.46932 / \operatorname{sfjdv1n3-004~}$

Received in: May 1st, 2020

Accepted in: June 30th, 2020

\author{
Isaac Ferreira Cavalcante \\ Sociologist, Specialist in Teaching in Higher Education, \\ Master in Political Science - UFPI \\ Member of NUDEP - Development and Poverty Research Center of the \\ Federal University of Piauí - UFPI, Brazil \\ E-mail: ferreira-cavalcanteif@gmail.com
}

\begin{abstract}
With the Third Industrial Revolution under way since the end of the last century, there have been profound changes in economic activity, moving from a large-scale economy to one of high value, anchored in the intensive use of advanced technology, that is, knowledge. To investigate the public administration managers position, about the construction of educational politics and the qualification of the workforce becomes essential. The purpose of this paper is to present, these ongoing economic changes, the percentage of investment in higher education public policy and the training of postgraduate students (Masters and Doctors) between 2000 and 2015 in Brazil. In this research, secondary data were used, available in CNPq, MEC, IBGE, ANFAVEA websites. Preliminary results indicate a positive linearity of educational variables and a significant change in the physiognomy of the Brazilian economy.
\end{abstract}

Keywords: Post-graduation, Industrial Revolution, Higher Education, Economy.

\section{INTRODUCTION}

This work objective is to reflect on the transformations that have taken place in the economy over the last fifteen years, that is, the transition from a Large Scale economy to a High Value economy. Large Scale production means a model that uses extensive workforce, with low educational capacity, through repetitive effort and a strict control in the production operations of goods and products, such as: transportation, clothing, household appliances, footwear, electronics, pharmaceuticals, chemicals, food, etc.

On the other hand, in High Value production, the profit does not come from scale or volume, but from the capacity of creating new connections among solutions and client's necessities being: companies, government organizations, interest associations, individuals, etc. (BERNARDONI FILHO, 2010, 47). In this case, production is not tied to a physical location, which can be performed wherever your developer is.

In high value production, the technologies that were responsible for the Third Industrial Revolution are privileged, specially the teleconference resources, laptop, iPhone, iPad, connected to a virtual net of information and data processing - internet. This kind of production does not require a 
separation between office and factory floor, from now on, the manufacture of goods and services takes place with a reduced work team, which should have high educational capacity, constant use of cognitive skills in the production operations of goods, products and services, such as: publicity campaign, development and maintance of softwares, products design, chips, microchips, scientific research, virtual applications, creation of products etc.

All of that has contributed to the resignification of the composition of types of human work. Therefore, this work question is to analyze if the changes in course have found effective actions, by public managers, in the recomposition of the Brazilian workforce through investment in higher education and the training of masters and doctors in public institutions between 2000 and 2015.

Anchored in Rovai, Baker, Ponton (2013), in the quantitative data investigation will be used the non experimental and descriptive model for trend analysis. These authors affirm that this type of archetype "[...] is used to generate a record of what is happening in a specific situation with a given population. And that the researcher will not attempt to exercise control over the phenomena" (ROVAI; BAKER; PONTON, 2013).

The time frame of this survey will be the period from 2000 to 2015. It is important to highlight that this investigation is oriented towards Brazilian reality. Among the intervening variables of this study we will have the formation and the public investment in individuals with high education formation. Each one of the information to be collected for this investigation will perform the function of providing an updated description that will serve as a diagnosis capable of producing inferences of possible trends underway in Brazil.

To understand how the transformation of the production and work environment can lead to new types of production and worker relations, an assessment of a team of authors, worried about this theme has been made, where a lot of transitional points has been found, such as: REICH (1991 and 2008); RIFKIN (1995); DE MASI (1999); CASTELLS (1999);

\section{DAVID; FORAY (2003); WERTHEIN (2007); POCHMANN (2011); GALETE (2013); BRIDI;}

BRAUNERT (2015). These authors expose concepts and dialogue about the possible resignifications or reconstructions of the trajectories that have occurred within the relations of the capitalist system, whose technological transformations have contributed to produce a new image, and it can be inferred that a new era of capital is underway.

The actual representation of capitalism in the XXI century can be noted through the dominance of new relations between State and Market. These two institutions present themselves as main charachters in this "brave new world." Thus, State and Market will be the agents involved in creations resultant from the application of new techniques of production allied to the virtuosity of the symbolic analysts. This work is formed in an introduction, a reflexion upon the transformation and charachteristics 
of the economy based in a large scale production and its transition to another, based in the intensive use of technological resources as machines, robots, computers etc., what we now call the economy based in high value production, and finally the results of the variables investment and training in higher public institution.

\section{CHARACTERISTICS OF THE LARGE-SCALE PRODUCTION SYSTEM AND ITS TRANSITION TO A HIGH VALUE ECONOMY}

At first, we seek to introduce the theme into literature, focusing in concepts and context that instructs the research problem, in other words, leading to the state of art. It is intended to present and inquire upon the change process that has been occurring in goods and services factory, as large-scale production is being overtaken by another of high value.

\subsection{A THE INDUSTRIAL PRODUCTION IN LARGE SCALE}

In a large scale system, the main preoccupation is the maximization of profit. That's why a model of production capable of intensifying the good creation and amplify the profits was developed. Therefore, the number of items and the consumers disposal are essential in this type of economy at the expense of its quality and durability. In many cases, the lifetime of an object is planned for a short time of duration, which ends up in its substitution, retro feeding this economical circle, one o that many economical agents define this type o scenario as a paradise to drain merchandising that are always available in stocks of industrial sheds.

For time reduction, the large scale model improved equipments and machines with the objective to maximize and turn the production more efficient. On the other hand, a series production system was developed, which demands concentration of thousands of workers in manufacturing conglomerates, in this case, the work is performed mainly by the sum of individual and repetitive efforts. In that space, every move is timed, with the objective of comply the production goals.

The model was implemented by Henry Ford, in the automobile industry in the United States of America, consisting the origin of the name "Industrial Fordism". This example is recurring to elucidate a production in large scale, because the fordism model has as charachteristic, an acumulation regime and a regulation mode that has as main feature, the mass production and organization of a productive space on automated assembly lines (JORGE, 2015). 
In large scale production, the time variable is primary. Therefore, to save time is to work more at the same period of time, this seems to be the motto of capitalist society. To increase the intensity of work, the capital uses payments forms asthe piecework wage.But there is no doubt that the rapid and continuous movement requires from the worker, the strictest discipline. More effort is needed, more attention, more regularity, more speed, more efficiency because, after all, you can't lose an instant of your working time (MENEGHETI; SAMPAIO, 2016, p.140).

Time can be money, by the way, it is not time itself that is transformed in money but the quantity of the time disposed at work form or in one or more worker whose physical or immaterial capacity can be transferred for a certain raw material that, when in addition to value of use, develops in that, the quality of merchandising which, in turn, becomes a capital good at the disposition of consumption and finally is transformed into money. In criticism of the political economy, Karl Marx defends in the first volume of The Capital that: "[...] a value of use or good, has value only because abstract human work is objectified or materialized in it". (MARX, 1996, p.168). Therefore, every product has in itself, after work crystallization through merchandising, an abstract time employed that was converted into monetary capacity. In other words, the longer the average working time contained in a product, the greater its final financial value to its recipient. The large scale production allowed the acceleration of production. According to Reich (1994) it was possible to produce many types of goods in a vertiginous way. For understandment, let's take the example of,

mechanical industries that processed tobacco, cereals, soap and canned foods increased their production fantastically by using continuous process manufacturing equipment. A cigarette machine developed in 1881 was so productive that fifteen of these machines were capable of meeting the entire annual demand for cigarettes in the United States alone.(REICH,1994, p.24).

Still as an example we can present the expansion of the economy in other sectors:

The production of iron doubled between 1870 and 1890; the steel production multiplied twenty times in the same period. As production equipment continued to be improved and plants expanded, the volume of production has grown. Only in the United States, the investments in the industry ascended from US\$2,7 billion in 1870 to US\$ 8,2 billions in 1899 ; the value of the manufactured products by every nation, in the same period, of US\$ 3,8 billion to US\$11 billion, in constant dollar (REICH,1994, p.25).

By this logic, the production paths were followed on a large scale that gradually obtained the mass adhesion of several countries, being very few nations that did not have this experience. In the case of Brazil for example, the most prominent sector is the automobile production (small and big size), which according to the National Association of Motor Vehicle Manufacturers (ANFAVEA), in a recent publication of the Brazilian Automotive Industry Yearbook, presents this idea of a maximization of production, enhanced by the large-scale industrial economic model. According to the yearbook of 1957 , 
the sector of automobile production, in Brazil, employed 9,773 workers and registered the manufacture of 30,542 vehicles in that year, in a $1 / 3$ proportion, i.e. for each worker on the production line, three cars were manufactured. In 2015, for example, the automobile sector employed 129,776 workers, reaching a record production of $2,429,421$ vehicles, in a proportion of $1 / 19$, i.e. for each worker on the production line nineteen cars were manufactured this year.

Between 1957 and 2015, the automobile industry in Brazil had an exponential growth of production and a significant drop in the contract employees, as can be seen in the graphic 1. These data indicate that the specialization of work combined with the increase and improvement of capital goods or their machinery applied to the vehicle industry, in a period of five decades in Brazil, made it possible to maximize production, with a real increase of the produced items and, with a minor utilization of human work, which leads automatically to financial gains.

Graphic 1 - Automotive industry in Brazil from $1957-2015$

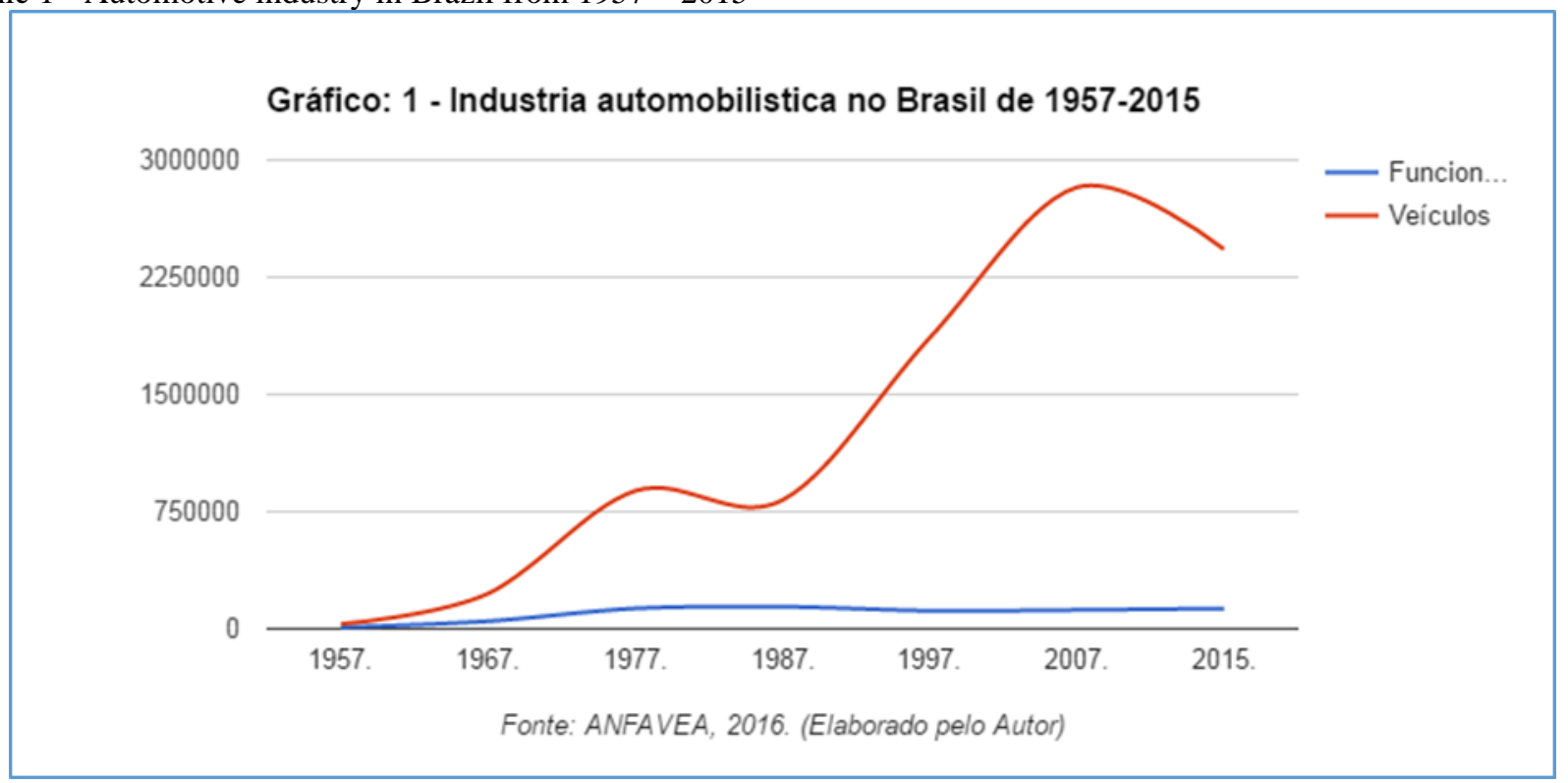

Source: Elaborated by the Author

In this context, it is necessary to inquire: what is the school requirement for operators of largescale production on cognitive capacity for work? Or rather, what is the relevance of schooling the mass of industrial workers for the execution of daily repetitive efforts? To understand this aspect of the work we rely on Domenico de Masi,

there is a long-standing predominance in companies of a disqualified, semi-illiterate, immigrant workforce, who does not even speak the same language as the boss or section chief, a poor workforce, recently left the countryside, psychologically and socially alien to the industrial world (DE MASI, 1999, p.143). 
In a large-scale production, schooling is not a factor of concern for the development of efficient production, all that is needed is physical capacity and little intellectual discernment, which is already enough for the sum of the efforts needed for production and the maximization of profits. After resignifying the value of the time and the schooling role in the large scale industrial production, this model of production was capable of other achievements, among them is the reordenation of the urban landscape and its habitant's routine.

One of the consequences of this reorganization has been population growth in the regions and cities with the existence of huge industrial parks, which have become polluting agents, in addition to the formation of large urban agglomerations. For example, “[...] the population from NYC quadrupled between 1860 and 1910.By 1860, Chicago had 109,260 inhabitants; by 1910 it was the second largest city in the US, with 2.2 million people (REICH,1994, p.30).

Still about the populational growth as one of the transformation results occurred in the industrialization process "[...] in a few more than 100 years, from 1780 to 1910, Paris has grown from 600,000 to 3 million; London, from 800 to 7 million; Berlin, from 180,000 to 3.5 million; New York, from 60,000 to 5.5 million" (DE MASI, 1999, p.146).

To confirm and present the results of the migrations as part of the effects caused by the industrialization on the formation of demographic dynamics and their social landscapes, we present in Chart 2 the data on the formation of Brazilian society distributed by sex and by urban $\mathrm{x}$ rural domicile from 1940 to 1996, according to the data extracted from the statistical yearbook of the Brazilian Institute of Geography and Statistics - IBGE, 1997.

Graph 2 - population behavior and distribution by sex, between urban and rural from 1940 - 1996. Men and Women

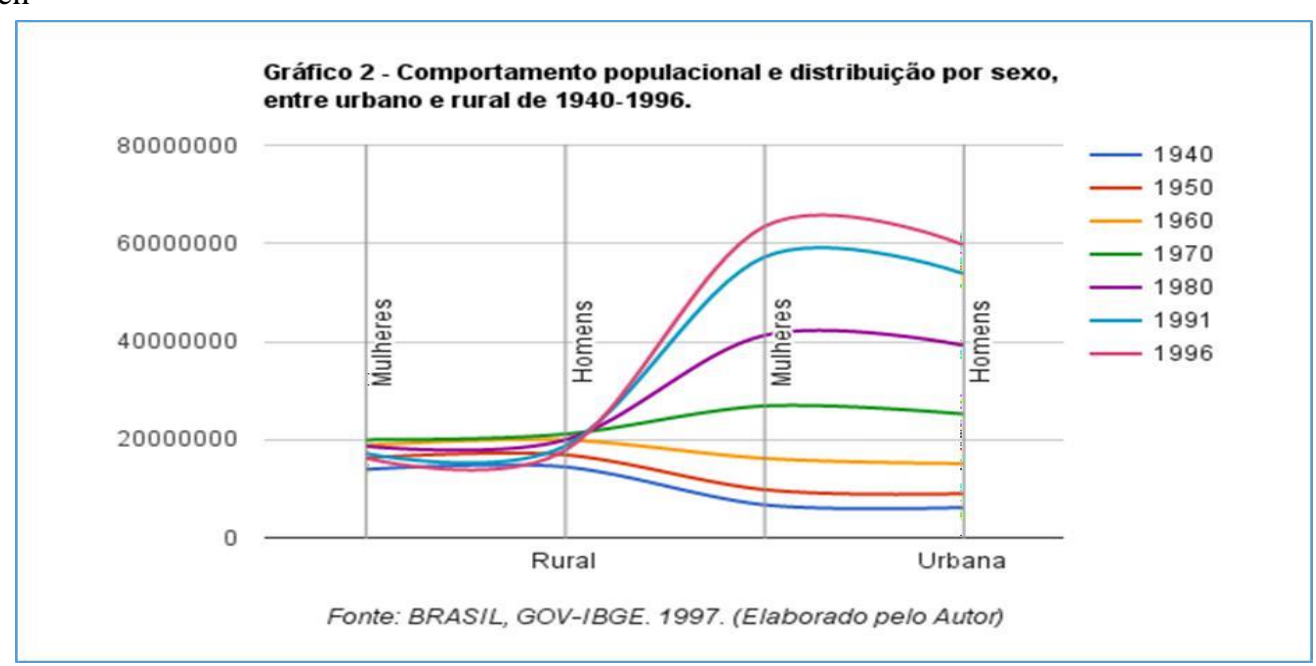


The presentation of the migration data of the Brazilian population is confirmed as an indicator of the ongoing changes in the process of development of industrialization in Brazil, which is in the phase of large-scale production. Between 1940 and 1996 a variation of the rural and urban population occurs as the demographic data show a dramatic growth in urban population.

The data of the rural and urban population behavior shows, in the graphic 3, with greater clarity, that the urban population keeps growing, in detriment to the rural population, which grew until the half of the 1970 decade, to then stagnate, continually declining to the present day. Approximately 2/3 of the inhabitants in Brazil live in urban centers.

Graphic 3: Urban and rural populational growth from 1940 to 1996

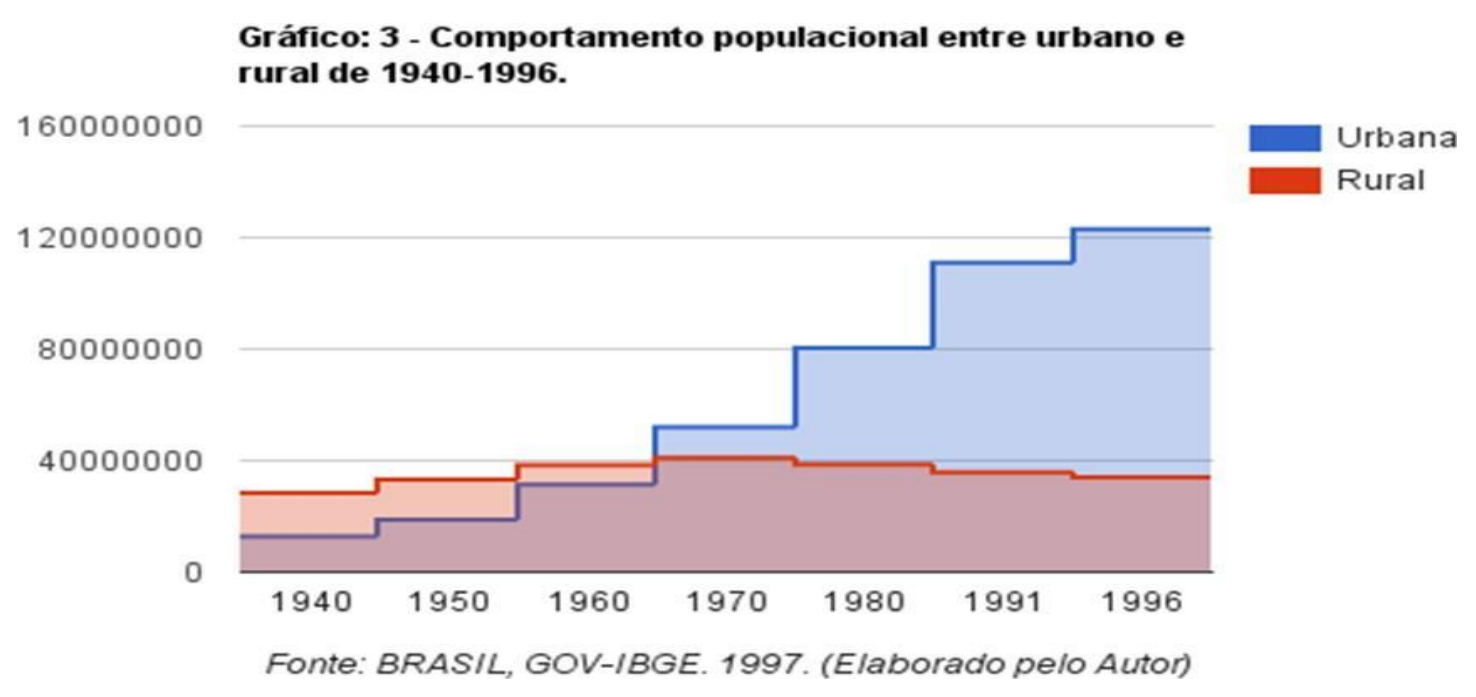

As first impression of the large scale industrial production, we found a resemblance in the United States of America, Japan, England, Germany and Brazil, of a new image about the production of goods representation, where the main changes take place in the value and meaning of time, the use of space and its population landscape and lastly in the level of education of its workers. These are the three charachteristics that are more relevant to understand the industrial capitalism in its large scale stage production. From this perspective, our attention will be in the identification of possible variations in an industrial economy based on high scale production to another of high value.

\subsection{A THE HIGH VALEU INDUSTRIAL PRODUCTION}

What we have seen in recent decades is a rapid process of change in the international economy. Companies and governments aiming to reduce the value of the production of goods and services have invested massively in science and technology. 
In these terms, it is no longer enough to make mass-produced products, standardized through assembly lines. The needs have become more complex, requiring intense application of knowledge about goods and services, that is, from now on, production results from the cognitive capacity to generate value. Thus, the high value production, with the intention to produce with less raw materials, manpower and energy, in addition to complying with flexible criteria, more specifically changing the focus from mass production to service of specific and particular customer needs (REICH, 1994, p. 75-76).

It is important to highlight that when it comes to meet the particular demands of customers, it is not argued here that flexibility provides productive elasticity to the point of increasing the capacity of companies to meet the tastes and needs of each individual.

It is not that, but that currently the resources of microelectronics and robotics have increased the capacity of industrial plants and planning to produce goods and services tinged according to the requirements of certain market sectors and even some particular demands, so the same plant enables the manufacture of a greater variety of products, closer to particular tastes and needs. When analyzing the literature, there is no precise definition of what a high value production is. Generally, there is a set of characteristics that minimize this type of production. We will try to outline a rough definition here, taking into account what is laid out in the work on the subject.

In this terms, the High Value production is a model based in an intensive use of knowledge through science and technology, which requires technicians and experts in know-how and and competence for the manufacture of products that can meet the needs of diversified consumers. Thus, its realization occurs in physical and virtual work spaces, requiring labor with high cognitive capacity for the creation of goods and services.

For this logic, the high value production differs itself substantially from the large scale, because the new generation of monetary values is indivisible connected to the capacity of knowledge application in a high level. Citing the North American example, Reich (1994, p. 76) affirms that,

\footnotetext{
in the United states, as in other principal areas of world economy, the most profitable field and the one with the fastest growth of siderurgy are no longer the large integrated, 5,000-strong steel ingots and racing plants. These are the steels intended for specific applications: corrosion-resistant steels (hot-dip galvanized or electro-galvanized) produced specifically for the automotive and applications industry; powder iron, which can be synthesized and forged into lightweight, precision-balanced parts used in crankshafts 2 and other highly requested engine components.
}

\footnotetext{
2 “[...] Tree mechanics that transforms into circular motion the alternative rectilinear motion of the piston-biela assembly of an engine". Available at: <http://www.dicio.com.br/virabrequim/>. Access on: 28 May 2016.
} 
To illustrate how high value production is applied in daily life we can cite the use of computers with robotic extensions to replace human labor in the livestock sector, specifically for the control and distribution of dairy cow feed consumption:

\begin{abstract}
Every cow uses an identification leash in the neck. An employee registers in the computer the number of each cows ration and the quantity of grains to be daily fed. The cow goes to the fees station. The badge in their necks makes contact with a metal plate in the feeder, allowing the computer to identify the cow. The computer verifies is it has already eaten its share of ration. If not, the computer activates a key that controls a drill. The drill turns, dumping the feed on the cow (RIFKIN, 1995, p. 125).
\end{abstract}

Other examples can be cited to instruct realities that present interfaces between computers and robotic in the economic activity, e.g. in agriculture Rifkin (1995) draws attention to a Israeli melon harvester called ROMPER (Robotic Melon Picker), we could also cite sowing machines and collectors used in the production of soya, sugar cane, cotton, corn, beans, tomatoes, etc. What can be seen is that today high-tech machines have been revolutionizing the farming activity.

The images in the Figure 1 illustrate certain types of machines that are used in agriculture nowadays.

Figure 1 - Machines with high technological capacity in agricultural production

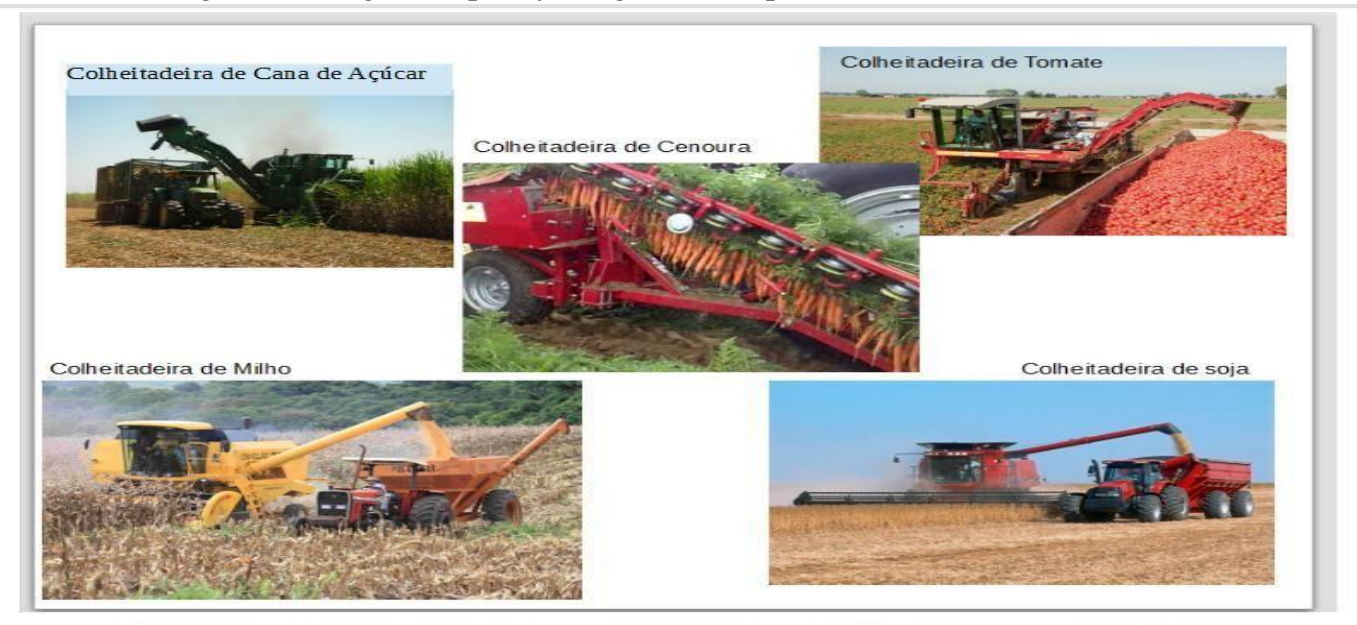

Fonte: Imagens disponíveis em Google: máquinas+agrícolas. Acesso em 26/06/2016.

At the same time that the use of computerized technology advance in the field, the high value industrial production, in general, has amplified the application in many types of products. This extensiveness can be seen in mass production of computers that in general, has standard operational patterns. In the perspective to amplify the utility of the computers and other remote communication equipments, their manufacturers had to reinvent e offer new services that could be available online for its users, as guarantee for it's production and profit continuity, what led to the creation of new usual tools in the virtual environment, for embedding in the equipments, for example of the softwares and applications. 
Their creators, by providing these virtual functions to their consumers of computers or remote communication equipment such as webcam, Iphone, tablet etc. demonstrate that they had at first a "natural" desire to make the flow of consumption of their products efficient.

What their creators did not realize the idea is that its improvements could modify at the root the old and traditional face-to-face relations of commerce, leading to a new dynamic in consumer relations, its virtualization. According to Takahashi (2000, p.18),

e-commerce has subverted the logic of traditional markets by imposing new features on them: easy access to information; reduction of transaction costs; replacement of traditional intermediaries by new types of agents that operate at the end of the production chain, with the final consumer, making all the connection with the producers of goods and services themselves; elimination of physical distances and uninterrupted operation in all regions of the world.

Within this scenario, such electronic services are available through the World Wide Web to the most diverse types of audiences, for the most diverse services, which can vary from the search for prices of habitation, temporary rental of houses, apartment, flat, online movies, virtual games, meetings of friends or lovers, virtual education environments, purchases and sales of any tangible or intangible product, stock exchange transactions, anywhere in the world. On the virtual environment, the creativity is infinite and everyone can float without leaving or taking his feet out of the territory he's in.

The most popular services in this type of trade are the services of buying and selling products online. For its organization it took the construction of a vast virtual network, known as e-commerce. What is noted in this scenario is the dematerialization of the traditional environment of buy and sell of tangible products and its substitution for the non presential or virtual space of relations between consumers through an environment of product offering.

Therefore, the e-commerce allowed a new pattern of capital development, that once was stuck in a physical space, tangible, and now is free and present in any virtual space can be viewed at any time and place by a mobile phone or other types of hardware. The e-commerce in Brazil, until the year 2000, registered a movimentation approximately of $\mathrm{R} \$ 50$ billions a year, among sells and buys of products and services through the virtual environment (TAKAHASHI, 2000).

Another example of this reality are the health services. They use little equipments with capacity of data transmission and clinic diagnosis about the patient situation, for medics in different locals. For example, "[...] a German system of remote cardiac monitorization, where the heart patients with their heart signals monitored, they have the possibility of these being transferred to their mobile phone and then transmitted to their doctor (KATZ; RICE; ACORD, 2006, p. 187), of which for each situation indicate a type of conduct to be performed by the patient. 
In limine. the most diverse studies began to be developed in laboratories and research centers using robotics in the treatment and diagnosis of diseases. Thus, machines and sophisticated equipments, controlled by computers, became ordinary in healthcare environment. Nowadays, there are robots and machine helping the realization of the most complex and delicate surgeries, allowing a "[...] tridimensional vision with zoom, increased dexterity, the minimization of movement, the possibility of tele-surgery, the elimination of surgeon's tremor and better ergonomics (DE MAGALHÃES, 2015, p.78).

The economy based on the production of high value has managed new social relations, id Est, created new ways of actions, interpersonal relations, representation of the world, etc., which has rapidly changed the way we live and do business globally. According to Rifkin (1995, p. 64),

is only now beginning to have a significant impact on how society organizes its economic activities. Numerically controlled robots, computers and advanced software are invading the last human sphere - the domains of the mind. Properly programmed, these new "intelligent machines" are capable of performing conceptual, managerial and administrative functions and of coordinating the production flow, from the extraction of the raw material to the marketing and distribution of the final product and services (RIFKIN, 1995, p.64)

The economy based in high value production has contributed to the reduction of time and distances between consumers and products, ensuring that this type of economy can generate greater profitability. According to Reich (1994, p.77), that higher income is explained in the perspective that,

these businesses are profitable both because customers are willing to pay high prices for goods or services that exactly meet their needs, and because high-value businesses cannot easily be imitated by competitors from other parts of the world who specialize in largescale production (REICH, 1994, p. 77).

Reich (1994) affirms that differently from the large scale production, which concentrate the production and its producers in manufacturing conglomerates, one of the characteristics of the economy based on high-value production is the decentralization of production and the reduction of direct operating costs.

According to the author idem p. 83), the

velocity and agility are so important for the high value company, that it can not be overloaded with heavy administrative costs, as office buildings, industrial facilities, equipment and payroll (...) what really matters, is the rapid identification of problems and solutions, the marriage of technical expertise with marketing experience blessed with strategic and financial acumen (...) offices, factories and warehouses can be rented; standardized component equipment can be purchased wholesale from low price manufacturers (many of them foreign); secretaries, administrative and accounting staff and workers for routine production can be hired on a temporary basis. 
Therefore, the decentralization of the physical environment of production, the capacity of problems identification and its solutions, the fragmentation of workforce, are the economy marks based in high value production. These particularities are part of what Reich call global web.

Global webs mean structures consisting of independent profit centers, formed by engineers and marketing specialists, strategic sales promoters located at the company's headquarters. For example, Companies as Johnson \& Johnson, which in 1990 were formed by 166 autonomous companies, the Hewlett-Packard, with nearly 50 units of business separate and distributed in different nations, form the configuration of business in the today's world (REICH, 1994, p.85).

Another archetype of global webs as the licensing ones. In this type, the headquarter company signs a contract with independent firms to use its trade name, sell its special formulations or market its technologies, the flow of products, the provision of services, stocks and advertising are controlled by computers and strategic sales promoters. An example of licensing is franchises that in 1988 in the United States already had 509,000 franchise stores and accounted for US\$ 640 billion in sales, or more than $10 \%$ of this country's GDP (REICH, 1994, p.86). At this web, the main products are: fast foods, hotels, health insurance, education and trainings, sport and recreation, cleaning and conservation.

In Brazil the licensing webs are quite significant. According to the Brazilian Franchising Performance Report 2015, published by the Brazilian Franchising Association (ABF), in the year 2015, 138,343 franchised establishments were fully operational in Brazil. Its distribution by cities represents $40 \%$ of Brazilian municipalities, with a total of 2,243 cities, offering 1,189,785 direct jobs. Among the 10 main franchise brands distributed by products and services sectors we have in $1^{\circ} \mathrm{O}$ Boticário, $2^{\circ}$ Subway, $3^{\circ}$ Cacau Show, $4^{\circ}$ Mattresses Ortobom, $5^{\circ}$ AM PM Mini Market, $6^{\circ}$ Mcdonald's, $7^{\circ}$ JET OIL, $8^{\circ} \mathrm{KUMON}, 9^{\circ} \mathrm{BR}$ MANIA and in $10^{\circ}$ Wizard languages. It is already possible to find the presence of Brazilian companies in 53 countries, with 134 differentiated networks, offering goods and services to their consumers (ABF, 2015).

The changes presented now require a new type of capabilities for the individuals involved in this global web of production. As a result, a set of skills are now required so that this gear of the economy can flow and guarantee the central objective of capital, which is the maximization and efficiency in the production of goods and services.

These new skills and abilities are organized from three new functions that will become established in the future, which are routine production services, personal services and symbolic analytical services (REICH, 1994, p.162). Routine production services [...] are performed repeatedly and endlessly - a step in a sequence that constitutes the manufacture of finished products, marketable on the world market (REICH, 1994, p.162). In most of the cases, this task is made by managers and supervisors 
of low and medium level in charge of line, management and section supervisors. Those practices are common in assembly industries of electronical components in printed circuits or in development of routine encoders for software programs (REICH, 1994, p.162).

The personal services are related to the routine services of production, they receive low wages that are measured by hour and volume production, has a average schooling that are strictly supervised. The personal services take place in direct contact with final consumers of the works. Among the categories re the retailers, hotel employees, janitors, waiters, cashiers, attendants and hospital assistants, asylum helpers, nannys, home nurses, taxi drivers, secretaries, hair stylists, physiotherapists etc., this function already represents 30\% of the North American workforce (REICH, 1994, p. 164).

The analytical symbolical services are inserted in every activity of problems solution, problems identification and strategical sale promotion. The main products are: data, words, oral and visual representation. Among the professions are: researchers, project engineering, of software, civilians, bioschnologists and sound, executive public relations, financials, lawyers, property developers, system analysts, information and organization specialists, consultants: culture, armament, marketing etc. (REICH, 1994, p.165).

About the analytical symbolical services, the production of goods is made by symbolical analysts. These work alone or in small groups, may be connected to large organizations, including global webs. Normally, this type of professionals present high level of schooling, going from graduation to postgraduation, its wages are tied to quality, originality, intelligence and, eventually, to the speed of which resolve new problems and promote the sale of their solutions (REICH, 1994, p.166).

As can be seen, unlike high-value production, large-scale production does not require, a priori, a highly educated workforce, since it is based on the repetitive use of the physical capacity of professionals. Lastly, in the high-value model, the intensive use of sophisticated machines in the field, in industry and trade, is now a new scenario. Ex never, it is counted the decrease of the work on the subject and increases the work on the information. In the consumer relations of goods and services, the traditional face-to-face environment is gradually replaced by virtual spaces of economic relations. In this type of economy, the ascension of the symbolical analyst starts to be unsustainable for countries which desires to be inserted in the new economy of the 21st Century. In Brazil, according to CAVALCANTE (2017, p 16), "the formation of the symbolical analysts a process in course, which has already begun in Brazil, but it does not represent the majority of workforce, only $1 / 3$ of the formal workers". 


\section{RESULTS}

In relation to public political investment of superior education, in the figure 1 , in the year 200 , the investment in Superior Education, starts with an estimated value of $\mathrm{R} \$ 9.000$ per student, over the decade, the variable of this behavior is significant, because of its positive linearity, which leads to closing in 2013 with an amount invested just over R \$ 21,000 per student in Higher Education. The data in figure 1, presents a positivity in the perspective of a concern with the formation of a workforce with high cognitive capacity, which leads to the statement that by 2013, Higher Education is presented as a priority of the Federal Government in this decade.

Figure 1 - Public investment per student in education in Brazil

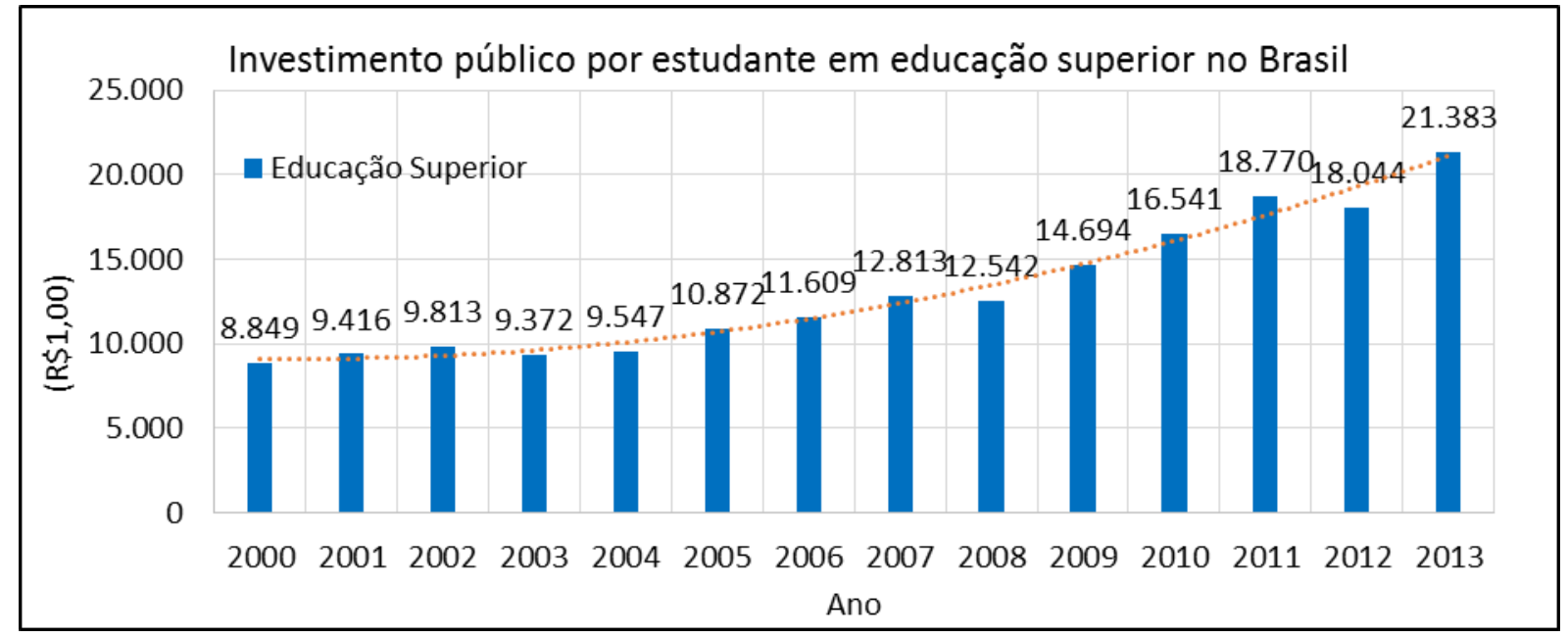

Source 1 - INEP/MEC - 2016, accessed in 10/08/2016. (Elaborated by the author).

The results on the training of postgraduates (Masters and Doctors) between 2000 and 2015 in Brazil can be seen in figure 2. In 2000 we have 3,314 Doctors and 4,700 Masters graduates. For the year 2015, the number is 18,347 Doctors and 41,294 Masters graduates. In the interval investigated the number of Doctors has quintupled, and that of Masters has increased tenfold. What this information indicates is that in the space of a decade and a half there has been a public policy of higher education, which has responded to the concerns in the formation of a workforce that can respond to the new and dynamic needs of the most diverse and broad spaces of production in the face of the ongoing transformations in the current economy. 
Figure 2

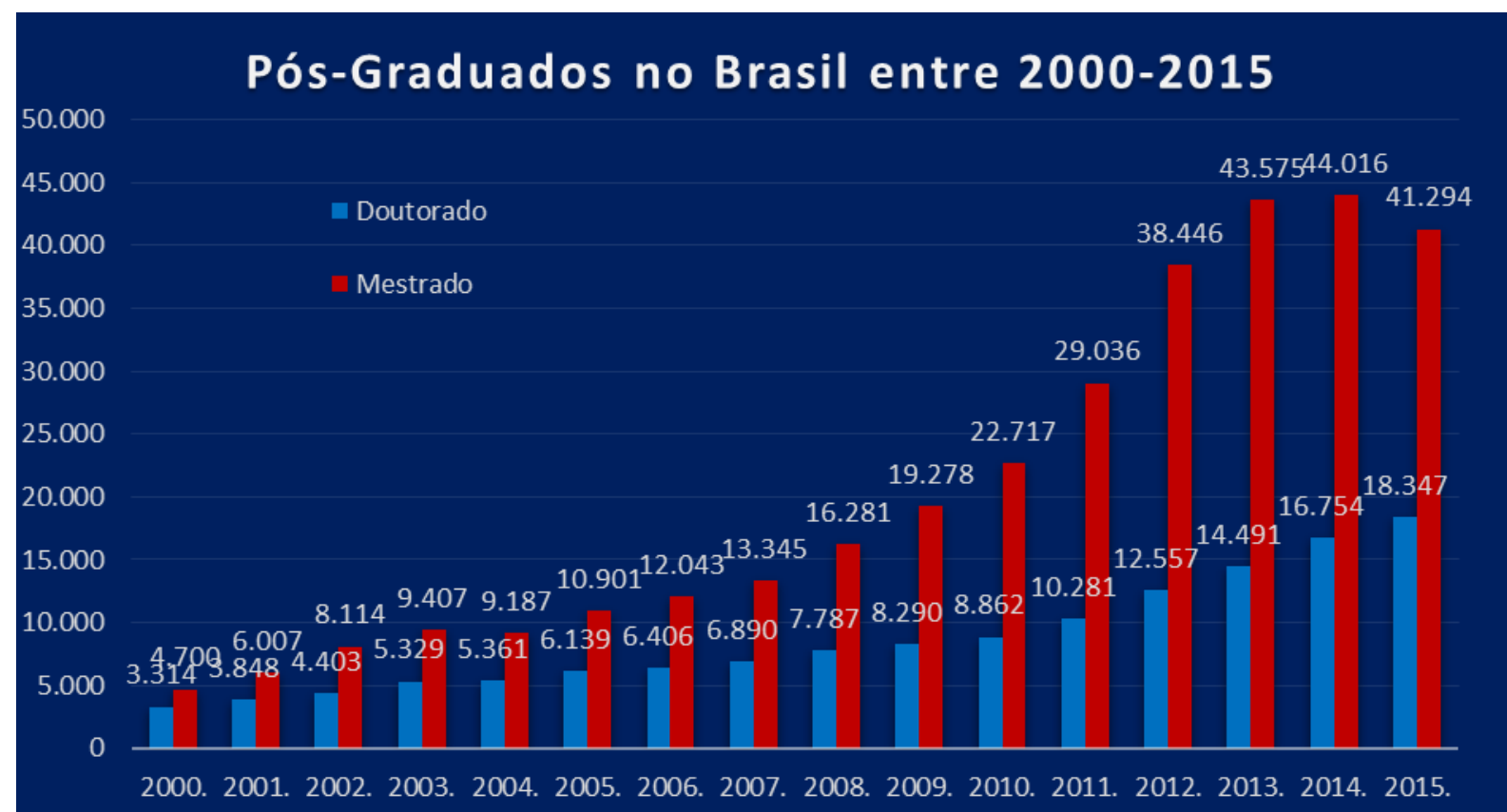

Source 2 - CNPq/Lattes. Accessed in 10/08/2016. (Elaborated by the author).

\section{FINAL CONSIDERATIONS}

The model of large-scale production has made possible modifications in the space of living of individuals, in the perception of the use of time as a measure of creation of monetary values, leading almost all of humanity to live in a new way, under the light and paths of industrialization, these ways of operating to produce goods are gradually receiving new technological tools, which are progressively replacing part of human work by machines and robots of high technology.

Part of these changes in the production space are consequences of the new discoveries that have resulted in the creation of computers, virtual spaces creation, production, sale and consumption of goods and services, what we call an economy based on high value production, whose products are handled, presented and built by symbolic analysts. For these symbolic analysts, to exist is indispensable the investment in Higher Education, which throughout the decade had a very positive behavior in Brazil, in the year 2013 with an amount invested approximately of R $\$ 21,000$ per student. About the formation of professionals with high scientific capacity, in one decade and a half 67,037 PhDs were graduated, which represents approximately for every 31 thousand people one has a $\mathrm{PhD}$, and a total of 152,782 Masters, and about 13 thousand people at least one has a Masters degree in Brazil.

The results found in this research are indicative that Brazil has taken significant steps in the field of higher education, towards the training of workers with high capacity, a central characteristic of the symbolic analyst in the high value economy.

On the reflection around how the public power has directed the educational formation of the population in Brazil, in order to be apt to the new forms of relations contained in the new era of changes 
and models of economic production, we can affirm that a part of the project to insert itself in this context has been produced, we can say, that we are at the beginning of this construction. Many Brazilians still do not have a higher education, and I believe that only when higher education is available to all, will we fully have one of the pillars of human development, scientific knowledge.

\section{REFERENCES}

ANFAVEA. Associação Nacional dos Fabricantes de Veículos Automotores. Anuário da Indústria Automobilística Brasileira. São Paulo, Anfavea, 2016. Available in: <http://www.anfavea.com.br/tabelas2014.html>. Accessed in: June 29th. 2016.

ASSOCIAÇÃO BRASILEIRA DE FRANCHISING - ABF. Relatório do Desempenho Franchising Brasileiro de 2015. São Paulo - SP. 24p. 2015. Disponível em

<http://www.abf.com.br/numeros-do-franchising/>. Accessed in: August 11th. 2016.

BRASIL, Gov. Ministério da Educação. INEP- Instituto Nacional de Estudos e Pesquisas Educacionais Anísio Teixeira. Indicadores financeiros Educacionais. Available in: http://portal.inep.gov.br/indicadores-financeiros-educacionais - Accessed in: August 10th. 2016.

, Governo Federal do. Ministério da Ciência, Tecnologia e Inovação - MCTI. Conselho Nacional de Desenvolvimento Científico e Tecnológico - CNPq. In. Evolução da Formação de Doutores e Mestres no Brasil. Portal: http://estatico.cnpq.br/painelLattes/evolucaoformacao/ Accessed in: August 10th. 2016.

BERNARDONI FILHO, José. A formação do analista simbólico: um estudo de caso sobre a Capacitação de profissionais na área de negócios. Dissertação (Mestrado em Organizações e Desenvolvimento) - Mestrado em Organizações E Desenvolvimento, FAE Centro Universitário, Curitiba, PR, 2010.

BRASIL. Instituto Brasileiro de Geografia e Estatística (IBGE). Dados históricos do Brasil, RJ- Rio de Janeiro. $\quad$ v.1 $1997 . \quad$ Available in: <http://www.ibge. gov.br/home/estatistica/populacao/censohistorico/1940 1996.shtm>. Accessed in: June 29th. 2016.

CRESWELL, Jonh W; PLANO CLARK, Vicki. L. Pesquisa de métodos mistos. Porto Alegre: Penso, 2013.

CAVALCANTE, Isaac Ferreira. A contribuição da produção de alto valor para a recomposição da força de trabalho brasileira. Dissertação (Mestrado em Ciência Política) -Universidade Federal do Piauí, 2017. Orientação: Prof. Dr. Raimundo Batista Santos Júnior. 85 f. 2017. Available in: https://repositorio.ufpi.br/xmlui/handle/123456789/1161

DE MAGALHÃES, João Luiz. Alguns aspectos bioéticos relativos à cirurgia robótica no Brasil. Revista Internacional de Humanidades Médicas, Madri - Espanha, v. 4. n.1, 2015.

DE MASI, Domenico. O Futuro do trabalho: fadiga e ócio na sociedade pós-industrial. Rio de Janeiro: José Olympio; Brasília: Edunb, 1999. 
DAVID, P.; FORAY, D. Fundamentos económicos de la sociedad del conocimiento. Comércio Exterior, v. 52, n. 6, p. 472-490, jun., 2003. Available in: http://www.proglocode.unam.mx/system/files/David\%20y\%20Forey\%202002_\%20Fundame ntos\%20econ\%C3\%B3micos\%20de $\% 201 \mathrm{a} \% 20$ sociedad\%20del\%20conocimiento Comercio \%20Exterior\%20Vol\%2052\%20No.\%206\%20\%5BDoc4\%5D.pdf . Accessed in: May 2nd. 2016.

JORGE, Vanessa de Arruda; ALBAGLI, Sarita. Papel da informação na área da qualidade: do fordismo ao capitalismo cognitivo. Transinformação [online], v. 27, n. 3, p. 245-253, 2015. Available in: 〈http://dx.doi.org/10.1590/0103-37862015000300006>.

Accessed in: May 2nd. 2016.

POCHMANN, M. O Brasil e a nova desindustrialização. Available in: <http://www.contee.org.br/noticias/artigos/art648.asp> Accessed in: June 9th. 2016.

KATZ, James E. RICE, Ronald E. e ACORD, Sophia. Usos da internet e de tecnologias móveis nos sistemas de saúde: abordagens sociais e organizacionais num contexto comparativo. In. A Sociedade em Rede, do Conhecimento à Ação Política. Organizadores: Manuel Castells e Gustavo Cardoso. 435p. 2006.

MARX, Karl. O capital: crítica da economia política. São Paulo. Editora Nova Cultura Ltda. Vol. 01 Tomo 1 . Tradução: Regis Barbosa e Flávio R. Kothe. (Coleção os Economistas).

MENEGHETTI, Gustavo; SAMPAIO, Simone Sobral. A disciplina como elemento constitutivo do modo de produção capitalista. Rev. katálysis [online]. 2016, vol.19, n.1, pp.135-142. ISSN 1414-4980. http://dx.doi.org/10.1590/1414-49802016.00100014. Accessed in: June 20th 2016.

ROVAI, Alfred P, BAKER, Jason D. \&amp; PONTON, Michael K. Social Science Research Design and Statistitics: a practitioner's guide to research methods and SPSS analysis. Watertree Press, 2013.

REICH, Robert. O trabalho das nações: preparando-nos para o capitalismo do século 21.

São Paulo: Educator, 1994.

RIFKIN, Jeremy. O fim dos empregos: o declínio inevitável dos níveis dos empregados e a redução da força de trabalho global. São Paulo: Makron Books, 1995.

TAKAHASHI, Tadao (Org.). Sociedade da informação no Brasil: livro verde. Brasília:, Ministério da Ciência e TECNOLOGIA (MCT), 2000. 